\title{
Water Supply and Temperature Effects on Some Nutritive Constituents of Direct Sown Onion
}

\author{
Attila OMBÓDI ${ }^{1 *}$, Andrea LUGASI ${ }^{2,3}$, Hussein Gehad DAOOD ${ }^{4,5}$, \\ Mária BERKI ${ }^{4}$, Lajos HELYES ${ }^{1}$ \\ 'Szent Istuán University, Faculty of Agricultural and Environmental Sciences, Institute of Horticulture, 1 Páter K, 2100, Gödöllo," Hungary; \\ ombodi.attila@mkkszie.bu("correspondingauthor);helyes.lajos@mkk.szie.hu \\ ${ }_{2}^{2}$ Budapest BusinessSchool, CollegeofCommerce, Catering and Tourism, Department of Catering, 9-11 Alkotmány, 1054, Budapest, Hungary; lugasiandrea@uni-bge.hu \\ ${ }^{3}$ National Institutefor Foodand Nutrition Science, 3/A Albert Flórián, 1097, Budapest, Hungary \\ ${ }^{4}$ National Agricultural Research and Innovation CentreFood Science Research Institute, 15 Herman Ottó, 1022, Budapest Hungary; m.berki@griibu

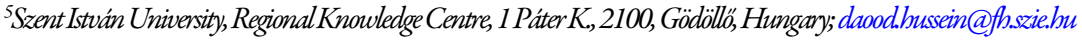

\begin{abstract}
Irrigation is a prerequisite for economical onion production under dry conditions. However, its effect on dry matter and nutrient content often remains a concern for growers. A direct sown onion hybrid was grown under open field, rain-fed and irrigated conditions for three years, investigating the effects of air temperature and water supply on some nutritive constituents. Dry matter, storage sugar, total flavonol and total polyphenol content showed strong positive correlation with average air temperature and negative correlation with water supply. However, irrigation had a positive effect on storage sugar and dry matter content. Presumably better water supply during dry periods ensured by irrigation provided the basis for higher photosynthetic production, and hereby more dry matter partitioning and accumulation in the bulb, a storage organ. An unexpected decrease in vitamin $\mathrm{C}$ content was experienced in 2011 and 2012, compared to the result of 2010, which was explained by the hot and dry conditions of the pre-harvest irrigation cut-off period. Fibre and ash content was found to be the most stable nutritional characteristics, affected neither by the environmental conditions, nor by the irrigation. Irrigation has proved to be very beneficial for direct sown onion, doubling bulb yield while not affecting the nutritive quality negatively.
\end{abstract}

Keywords: irrigation, dry matter, storage sugars, vitamin C, polyphenols

\section{Introduction}

Onions can be grown under different environmental conditions, being a well adaptable crop (Brewster, 2008). However, onions grown for their dried bulbs are rather difficult to produce, as environmental factors impact growth and development to a great extent (Welbaum, 2015). Literature categorises onion as a cool-season crop, tolerant of frost but with higher optimum temperature range than most cool-season vegetables (Rubatzky and Yamaguchi 1997). Relative growth rate of onion increases linearly between $6{ }^{\circ} \mathrm{C}$ and $20{ }^{\circ} \mathrm{C}$ (Brewster, 2008). Supraoptimal temperatures negatively affect yield, bulb quality, dry matter content and bulb shape of onion (Welbaum, 2015), while lower temperatures cause later foliage fall down and therefore longer duration of bulbing (Khokar, 2008). Besides affecting the growth of bulbs, temperature also affects nutritional values, flavour intensity, dry matter and sugar content of the bulb (Lee and Suh, 2009).

Although onions can tolerate periods of draughts, yield is heavily influenced by draught stress (Brewster, 2008; Ombódi et al., 2013). Based on published results, it is unquestionable that under dry conditions appropriate irrigation increases onion yield to a great extent (Enciso et al., 2009; Pejic et al., 2011; Leskovar et al., 2012; Ombódi et al., 2013). However, negative effects of irrigation on nutritional values, dry matter content and storage life often remains a concern for growers producing onions for quality markets (Pérez-Ortolá and Knox, 2015). Dry matter content is among the most important quality characteristics of onion bulbs, strongly influencing the method of utilisation, storability and nutritive value. About $60 \%$ to $80 \%$ of the onion dry matter is composed of storage sugars, with the remaining part is being formed by fibres, ash and some other components (Brewster, 2008).

Beneficial health effects of onions are attributed to the wide range and to the high concentration of phytonutrients present in this crop (Corzo-Martínez et al., 2007). Onion is one of the most important vegetable sources of flavonoid antioxidants (Tiwari and Cummins, 2013). Onion flavonoid concentration was found to be influenced by climatic factors at a great extent (Patil et al., 1995).

The objective of the present study was to investigate the effect of air temperature and water supply on the content of dry matter and some phytonutrients of direct sown onion under rain-fed and irrigated conditions. 
246

\section{Materials and Methods}

Environmental conditions

The present research was conducted between 2010 and 2012 in Gödöllö, Hungary ( $47^{\circ} 61^{\prime} \mathrm{N}, 19^{\circ} 32^{\prime} \mathrm{E}$ ) at the experimental farm of Szent István University. The soil at the experimental sites was a loamy sand classified as Cambisol. Soil chemical analysis reported neutral $\mathrm{pH}$ (6.94-7.20), low electrical conductivity $\left(0.17-0.25 \mathrm{dS} \mathrm{m}^{-1}\right)$ and medium organic matter content (0.91$1.61 \%)$.

Air temperature and precipitation were recorded continuously by a Campbell CR21X meteorological data logger (Campbell Scientific Inc., Loughborough, U.K.). Weather conditions for the three growing seasons were considerably different (Table 1); 2010 was a cool and wet year, while 2011 and 2012 were hot and dry. The lowest average air temperature was recorded in 2010, while that parameter was higher by $0.8^{\circ} \mathrm{C}$ and $1.2{ }^{\circ} \mathrm{C}$ for 2011 and 2012, respectively. Especially June and August was cooler in 2010 compared to the other two years, while 2011 had far the coolest July of the three years (Table 1).

Precipitation conditions were also very different in the three growing periods. Total amount of precipitation was less than half in 2011 and 2012, compared to that of 2010, with the main differences occurring in May, in June and especially in August (Table 1). In August and in September there was almost no precipitation in 2011 and in 2012, while plenty of rain fell in 2010. July proved to be rainier in 2011 and in 2012 than in 2010. As a summary of climatic monitoring data it can be stated that years 2011 and 2012 were less favourable and more stressful for onions than year 2010, especially during the last third of the growing periods.

\section{Cultivation method and experiment setting}

Seeds of a long-day type, bronze-coloured hybrid, 'Mundo' (Syngenta Seeds B.V., Enkhuizen, the Netherlands), were sown in double rows spaced $25 \mathrm{~cm}$ apart, on the 20th April, 25th March and 20th March in 2010, 2011 and 2012, respectively. The late sowing in 2010 was due to weather conditions. Distance between neighbouring double rows was left $50 \mathrm{~cm}$. Seeds were placed at a density of 30 seeds per metre in the rows, resulting in $\approx 0.8$ million seeds per hectare. Fertilizers were applied four times during the growing period at a total quantity of $175 \mathrm{~kg} \mathrm{ha}^{-1} \mathrm{~N}, 20$ $\mathrm{kgha}^{-1} \mathrm{P}$ and $224 \mathrm{kgha}^{-1} \mathrm{~K}$.

Rain-fed and irrigated plots were established on homogeneous area each year, with guard rows between. Plots were composed of four $27 \mathrm{~m}$ long double rows, resulting in $81 \mathrm{~m}^{2}$ plot size. One double row corresponded to one replication. Drip lines [Siplast mono $\left(20 \mathrm{~mm}\right.$ i.d., $30 \mathrm{~cm}$ emitter spacing, $1.71 \mathrm{~h}^{-1}$ emitter discharge at $100 \mathrm{kPa}$ ); Irritec S.p.A., Capo d'Orlando, Italy] were installed between the double rows for irrigation. Irrigation scheduling was based on tensiometer (Tensiometer

Table 1. Weather conditions of the three growing periods

\begin{tabular}{lcccccc}
\hline Year & $\begin{array}{l}\text { Sowing - } \\
\text { 30 }\end{array} 0^{\text {th }}$ April & May & June & July & $\begin{array}{c}1^{\text {st }} \text { August } \\
\text { - harvest }\end{array}$ & $\begin{array}{c}\text { Whole } \\
\text { period }\end{array}$ \\
\hline \multicolumn{7}{l}{ Average air temperature $\left({ }^{\circ} \mathrm{C}\right)$} \\
2010 & 12.4 & 15.5 & 18.8 & 22.7 & 18.3 & 18.3 \\
2011 & 11.4 & 15.8 & 20.1 & 19.9 & 21.0 & 21.0 \\
2012 & 11.2 & 16.5 & 20.2 & 23.0 & 20.7 & 20.7 \\
Precipitation $(\mathrm{mm})$ & & & & & \\
2010 & 0.2 & 190.0 & 149.5 & 51.1 & 148.8 & 588.6 \\
2011 & 29.8 & 31.0 & 60.8 & 67.5 & 11.8 & 200.9 \\
2012 & 17.3 & 46.4 & 87.9 & 100.4 & 4.5 & 256.5 \\
\hline
\end{tabular}

Classic 8060; Stelzner GmbH, Nürnberg, Germany) readings; set point for irrigation start was $35 \mathrm{kPa}$ soil water tension. In order to ensure adequate stand establishment, plants for both treatments were irrigated during the emergence period with a total amount of $15 \mathrm{~mm}, 15 \mathrm{~mm}$ and $21 \mathrm{~mm}$ of water in 2010 , 2011 and 2012, respectively. After this period four, nine and 17 irrigations were applied with a total amount of 65, 110 and 202 $\mathrm{mm}$ in 2010, 2011 and 2012, respectively. Irrigation cut-oft period was applied from late August.

Onions were harvested when their necks were completely dry on the 15th, 9th and 18th of September in 2010, 2011 and 2012, respectively. Prior the harvest, a randomly selected sampling area was allocated in each double row with a size of twelve running meters. Yields were calculated based on the weight of bulbs harvested from these areas. A $2 \mathrm{~kg}$ sample with representative average bulb size was selected for chemical analysis from each replication.

\section{Chemical analysis}

Following the removal of the neck, basal plate and skin, dry matter content was determined after freeze drying of homogenized onion bulbs. Carbohydrate content was measured based on the method of Abidin and Maier (1980). Vitamin C content was determined by a high-performance liquid chromatography (HPLC) method based on the European Standard (2003). The analyses of total polyphenols were performed according to the Folin-Denis method, spectrophotometrically at $760 \mathrm{~nm}$, using catechin as standard (AOAC, 1990). Flavonol detection was carried out by an HPLC method described by Ombódi et al. (2013). Ash content was measured gravimetrically. Dietary fibre was determined gravimetrically after an enzymatic hydrolysis of proteins and carbohydrates (Codex Alimentarius Hungaricus, 2008).

\section{Statistical analysis}

Results were expressed as the mean of the four replications plus/minus standard errors. Statistical analysis was performed using SPSS 22 for Windows (IBM Co., New York, NY) and Microsoft Excel 2007 Analysis Toolpack (Microsoft Corporation., Redmond, Washington) software. In all tests $\alpha$ was set to 0.05 . Data were compared by two-way analysis of variance (ANOVA) with the factors being growing year (2010, 2011 and 2012) and water supply (rain-fed and irrigated). Yield and nutritive constituents were the dependent variables. Prior to model fitting, residual homogeneity and normal distribution was checked. Mean separations were performed using Fisher's protected least significant difference test. For further analysis of temperature and irrigation effects on nutritive constituents, correlation analyses were performed separately on irrigated and on rain-fed data.

\section{Results and Discussion \\ Yield}

About 50-60 $\mathrm{t} \mathrm{ha}^{-1}$ is considered to be an average yield for irrigated direct seeded onions in Hungary. In the present experiment onion bulb yields were 15.8 and $37.8 \mathrm{t} \mathrm{ha}^{-1}$ in 2010 , 37.0 and $56.5 \mathrm{tha}^{-1}$ in 2011, and 20.5 and $50.4 \mathrm{t} \mathrm{ha}^{-1}$ in 2012 for the rain-fed treatment and the irrigated treatment, respectively. Irrigation resulted in significantly higher yield in all the three years, in agreement with previous findings (Enciso et al., 2009; Pejic et al., 2011; Leskovar et al., 2012). In the average of the three years irrigation doubled the yield. Considering the effect of 
the year, 2010 produced significantly the lowest yield. Based on the results of an experiment conducted with onion grown from set on the same experimental farm at the same period (Ombódi et al., 2013), it can be stated that this yield-decrease was not caused by environmental conditions but too late sowing time. As for the other two years, no statistical difference was found between the yields in the irrigated plots, while yield in 2011 was significantly higher than in 2012 in the rain-fed control. Thus yield was much more predictable under irrigated conditions.

\section{Dry matter and storage sugar content}

Dry matter content of bulbs ranged between $9 \%$ and $12 \%$, representing an average level for direct sown onions (Brewster, 2008). Dry matter content was significantly affected both by the growing year and the water supply (Table 2). The highest dry matter values were measured in the warmest year of 2012, while the lowest ones were registered in the coolest and rainiest year of 2010. For both treatments very strong, highly significant positive correlations were found between average air temperature of the growing season and dry matter content (Table 3 ). The one month shorter growing period in 2010 could also contribute to the lower dry matter accumulation in the bulbs in that year.

Dry matter content also significantly correlated with the amount of supplied water, and this correlation was, evidently, much stronger in the case of the rain-fed treatment than for the irrigated one (Table 3). The correlation was negative; the rainiest year produced the lowest dry matter level. However, irrigation slightly increased the dry matter content in all the three years and reached significant levels in 2012 (Table 2). Furthermore, investigating data of all the three years together, result of the twoway ANOVA showed that irrigation had a significant positive effect on dry matter content (Table 2), while increasing the yield.

Onion dry matter is mainly composed of storage carbohydrates (Brewster, 2008). Accordingly, a strong positive correlation $(\mathrm{R}=+0.883, \mathrm{P}<0.001, \mathrm{~N}=24)$ was found between storage carbohydrate and dry matter content. Thus, tendency of storage carbohydrate data was very similar to that of dry matter content described above (Table 2). Correlations between the amount of supplied water or average air temperature and storage carbohydrate content was slightly weaker than those of dry matter but still highly significant (Table 3). Additionally, storage carbohydrate content was reported significantly higher in the irrigated treatment not only in the hottest year of 2012, but also in the other two years. Based on our findings, higher average air temperature resulted in higher sugar concentration and consequently higher dry matter content in the temperature range of the experiments $\left(16-18^{\circ} \mathrm{C}\right.$ average). This result corresponds to the finding of Lee and Suh (2009), who reported higher sugar concentration in onion bulb at $20^{\circ} \mathrm{C}$ than at $15^{\circ} \mathrm{C}$.

In our experiment irrigation had a definite positive effect on storage sugars and dry matter accumulation. Based on the literature effect of irrigation on dry matter and sugar content of onions is ambiguous. Enciso et al. (2009), Leskovar et al. (2012) and Ombódi et al. (2013) found that drip irrigation had no effect on total soluble solid (TSS) and dry matter content in onion. Kahlon et al. (2011) reported increasing TSS level as a result of irrigation. On the contrary, Pejic et al. (2011) experienced reduced TSS content when applying sprinkler irrigation.

In this experiment storage sugar and dry matter content became higher in years with lower amount of precipitation. At the first sight, positive effect of less precipitation and positive effect of irrigation seem to be controversial. However, it should be considered that onion bulb is a storage organ and its carbohydrate and dry matter content is a result of a several month long accumulation process. Pérez-Ortolá and Knox (2015) noted that optimal water supply results in more developed canopy, which can provide a base for higher photosynthetic production and, as a result, increased dry matter

Table 2. The effects of growing year and irrigation on dry matter content of onion and its main components expressed in $\mathrm{gkg}^{-1}$ fresh weight (mean \pm S.E.)

\begin{tabular}{lcccc}
\hline Year/Treatment & Dry matter & Storage carbohydrates & Fibres & Ash \\
\hline 2010 & & & & \\
Rain-fed & $87.4 \pm 1.1 \mathrm{~d}^{*}$ & $52.6 \pm 1.2 \mathrm{e}$ & $24.9 \pm 1.5$ & $4.53 \pm 0.14$ \\
Irrigated & $92.6 \pm 2.7 \mathrm{~d}$ & $61.9 \pm 2.1 \mathrm{~d}$ & $23.9 \pm 1.4$ & $4.18 \pm 0.13$ \\
2011 & & & & \\
Rain-fed & $107.4 \pm 1.6 \mathrm{c}$ & $65.4 \pm 0.7 \mathrm{~cd}$ & $25.3 \pm 1.5$ & $4.25 \pm 0.13$ \\
Irrigated & $109.7 \pm 3.2 \mathrm{c}$ & $74.3 \pm 4.4 \mathrm{ab}$ & $26.0 \pm 1.2$ & \\
2012 & & & & \\
Rain-fed & $117.8 \pm 2.6 \mathrm{~b}$ & $70.3 \pm 4.2 \mathrm{bc}$ & $27.2 \pm 5.0$ & $4.60 \pm 0.25$ \\
Irrigated & $126.5 \pm 2.3 \mathrm{a}$ & $80.0 \pm 2.1 \mathrm{a}$ & $29.6 \pm 3.1$ & \\
\hline Significance (P value) & & & & \\
Year (Y) & $<0.001$ & $<0.001$ & 0.743 & 0.231 \\
Irrigation (I) & 0.017 & $<0.001$ & 0.336 & 0.731 \\
Yx I interaction & 0.419 & 0.991 & 0.823 & 0.479 \\
\hline
\end{tabular}

${ }^{*}$ Mean separation within columns by Fisher's protected least significant difference test at $\mathrm{P}<0.05$

Table 3. Correlation coefficients for the connection between water supply or average air temperature during the growing period and the measured nutritive constituents of onion $(\mathrm{N}=12)$

\begin{tabular}{|c|c|c|c|c|c|c|c|c|}
\hline \multirow{3}{*}{$\begin{array}{l}\text { Dependent variable } \\
\text { ( } \mathrm{g} \mathrm{kg}^{-1} \text { fresh weight } \\
\text { Dry matter }\end{array}$} & \multicolumn{4}{|c|}{ Average air temperature } & \multicolumn{4}{|c|}{ Water supply } \\
\hline & \multicolumn{2}{|c|}{ Rain-fed } & \multicolumn{2}{|c|}{ Irrigated } & \multicolumn{2}{|c|}{ Rain-fed } & \multicolumn{2}{|c|}{ Irrigated } \\
\hline & +0.966 & $* * * a$ & +0.928 & $* * *$ & -0.857 & *** & -0.495 & * \\
\hline Storage carbohydrates & +0.857 & $* * *$ & +0.816 & $* *$ & -0.789 & ${ }^{* *}$ & -0.565 & $*$ \\
\hline Fibres & +0.155 & NS & +0.511 & $*$ & -0.097 & NS & -0.214 & NS \\
\hline Ash & +0.006 & NS & +0.443 & NS & +0.186 & NS & -0.176 & NS \\
\hline Vitamin C & -0.628 & $*$ & -0.860 & $* * *$ & +0.515 & $*$ & -0.366 & NS \\
\hline Total flavonols & +0.894 & $* * *$ & +0.925 & $* * *$ & -0.742 & $* *$ & -0.610 & * \\
\hline Total polyphenols & +0.903 & $* * *$ & +0.844 & $* * *$ & -0.691 & * & -0.411 & NS \\
\hline
\end{tabular}

$\left(\mathrm{a}^{* * *}=\mathrm{P}<0.001,{ }^{* *}=\mathrm{P}<0.01,{ }^{*}=\mathrm{P}<0.05, \mathrm{NS}=\right.$ nonsignificant $)$ 
248

accumulation and partitioning in the bulb, a storage organ. Thus, sugar and dry matter accumulation was considerably lower in the rain-fed treatment compared to the irrigated one during dry periods. This finding is in correspondence with the statement of Brewster (2008) that the conversion efficiency of absorbed light to photosynthetic products is decreased by the lack of irrigation under dry weather conditions.

\section{Fibre and ash content}

Fibre content ranged between $24 \mathrm{~g} \mathrm{~kg}^{-1}$ and $30 \mathrm{~g} \mathrm{~kg}^{-1}$ (Table 2 ) in the experiment, considered slightly higher than previously reported values of $14-24 \mathrm{~g} \mathrm{~kg}^{-1}$ (Rodríguez Galdón et al., 2009). Ash content data, ranging between $4 \mathrm{~g} \mathrm{~kg}^{-1}$ and $5 \mathrm{~g} \mathrm{~kg}^{-1}$ (Table 2) fell in the middle of the range of $2-4 \mathrm{~g} \mathrm{~kg}^{-1}$ to $8-10 \mathrm{~g} \mathrm{~kg}^{-1}$ of earlier published results (Thompson et al., 2005; Rodríguez Galdón $e t$ al., 2009) and corresponded well to the measured medium level dry matter content. Correlations between the investigated environmental factors and fibre or ash content were not significant in most of the cases (Table 3).

Studies about temperature and irrigation effect on onion ash and fibre content are scarce. In our experiment concentrations of fibres and ash were much more stable than that of dry matter and storage carbohydrate, as neither the year, nor the irrigation affected the content of fibres and ash (Table 2). Presumably the content of these components is mainly determined by genetic background, their accumulation was not affected by the environmental factors (like air temperature and water supply) in a great extent under the conditions of this experiment.

\section{Phytonutrients}

Onion bulb vitamin $\mathrm{C}$ concentrations were measured between $27 \mathrm{mg} \mathrm{kg}^{-1}$ and $60 \mathrm{mg} \mathrm{kg}^{-1}$ on a fresh weight basis, which fell within the range of $15 \mathrm{mg} \mathrm{kg}^{-1}$ and $84 \mathrm{mg} \mathrm{kg}^{-1}$ compiled by Caruso et al. (2014). Vitamin C concentration was not affected by irrigation; however, year had a pronounced effect on it (Table 4). Vitamin $C$ content of both treatments was measured as the highest in 2010, being the coolest and the rainiest year of the experiment; and was the lowest in 2012, a hot and dry year with stressful conditions during the last third of the growing period. Significant negative correlations were found between average air temperature and vitamin $\mathrm{C}$ content for both treatments, being stronger for the irrigation treatment than for the rain-fed one (Table 3).

The tendency of these vitamin $\mathrm{C}$ data contradicts several previous findings. For example in their 3-year onion study Franczuk et al. (2009) recorded the lowest vitamin C content in the year of the most favourable weather condition. In a previous study, conducted with onions grown from set using the same experimental and analytical methods as in this research, it was also found that favourable weather conditions induced lower vitamin C accumulation (Ombódi et al., 2013). Smirnoff(2011) noted that vitamin $C$ accumulation is usually higher under unfavourable weather conditions, as this compound has a key role in abiotic stress tolerance. Generally, higher light intensity and temperature during the growing season and less frequent irrigation result in greater vitamin $\mathrm{C}$ content in fruits and vegetables (Lee and Kader, 2000). On the other hand, it is also well known that vitamin $C$ loss after harvest is accelerated at higher temperature. Furthermore, it was reported that some citrus fruits even contained more vitamin $C$ when grown under cool temperatures than hot temperatures (Lee and Kader, 2000). It is presumed that in 2011 and 2012, under the hot and dry
Table 4. The effects of growing year and irrigation on the concentration of some phytonutrients in direct sown onion, expressed in $\mathrm{g} \mathrm{kg}^{-1}$ fresh weight (mean $\pm \mathrm{SE}$ )

\begin{tabular}{lccc}
\hline Year/Treatment & Vitamin C & $\begin{array}{c}\text { Total } \\
\text { flavonols }\end{array}$ & $\begin{array}{c}\text { Total } \\
\text { polyphenols }\end{array}$ \\
\hline 2010 & & & \\
Rain-fed & $53.9 \pm 2.9 \mathrm{ab}^{*}$ & $509 \pm 30 \mathrm{~d}$ & $695 \pm 36 \mathrm{c}$ \\
Irrigated & $60.0 \pm 2.9 \mathrm{a}$ & $493 \pm 18 \mathrm{~d}$ & $724 \pm 41 \mathrm{c}$ \\
2011 & & & \\
Rain-fed & $44.6 \pm 2.3 \mathrm{bc}$ & $779 \pm 49 \mathrm{c}$ & $874 \pm 39 \mathrm{~b}$ \\
Irrigated & $47.5 \pm 3.6 \mathrm{abc}$ & $874 \pm 72 \mathrm{bc}$ & $918 \pm 55 \mathrm{~b}$ \\
2012 & & & \\
Rain-fed & $36.3 \pm 7.9 \mathrm{~cd}$ & $1006 \pm 78 \mathrm{ab}$ & $1117 \pm 36 \mathrm{a}$ \\
Irrigated & $27.1 \pm 4.2 \mathrm{~d}$ & $1082 \pm 40 \mathrm{a}$ & $1158 \pm 73 \mathrm{a}$ \\
Significance (P value) & & & \\
Year (Y) & $<0.001$ & $<0.001$ & $<0.001$ \\
Irrigation (I) & 0.985 & 0.278 & 0.346 \\
Yx I interaction & 0.210 & 0.589 & 0.987 \\
\hline$*$ *
\end{tabular}

${ }^{*}$ Mean separation within columns by Fisher's protected least significant difference test at $\mathrm{P}<0.05$

conditions of the irrigation cut off period coinciding with the fall down and bulb ripening period, temperature of the unshaded bulbs left in the field became very high, resulting in higher loss, and consequently lower content of vitamin C.

In the present study, total flavonoid and total polyphenol content varied from $492 \mathrm{mg} \mathrm{kg}^{-1}$ to $1083 \mathrm{mg} \mathrm{kg}^{-1}$ and from 695 $\mathrm{mg} \mathrm{kg}^{-1}$ to $1158 \mathrm{mg} \mathrm{kg}^{-1}$ on a fresh weight basis, respectively (Table 4). These data correspond well to previously published results for bronze-coloured onions (Mogren et al., 2006; Slimestad et al., 2007). Total flavonol and total polyphenol concentrations were the highest in 2012 and the lowest in 2010 (Table 4), showing significant positive correlations between average air temperature and their concentrations for both the rain-fed and the irrigated treatments (Table 3). These results are in agreement with previous reports stating that onion flavonoid levels considered the highest under hot and dry conditions (Rodrigues et al., 2011) and that positive correlation between global radiation and onion quercetin concentration exists (Mogren et al., 2006). Treutter's (2010) general statement that polyphenol accumulation is higher under stress conditions proved to be true for our experiment.

Vitamin C, total flavonol and total polyphenol content was not affected by irrigation according to the results of two-way ANOVAs (Table 4). While irrigation had no significant effect on concentrations of the investigated phytonutrients within a given year (Table 4), statistically significant correlations were found between the amount of available water and phytonutrient concentration in the case of the rain-fed treatment (Table 3). Sign of the correlation was positive for vitamin $\mathrm{C}$ and negative for total flavonols and total polyphenols. This latter finding again justifies the general theory of higher polyphenol accumulation under stress conditions, but slightly contradicts with the results of some previous onion studies reporting no correlation between water supply and flavonol content (Mogren, 2006; Leskovar et al., 2012).

\section{Conclusions}

The current study revealed that irrigation of direct sown onion is strongly recommendable even from the viewpoint of product nutritional quality. Based on our results, irrigation was very beneficial, it doubled the yield without decreasing the content of the measured nutritive constituents. The year $\mathrm{x}$ water 
supply interaction had no significant effect on the results of any of the investigated parameters. Thus, tendency of the results regarding the effect of irrigation was steady, not affected by the climatic conditions of different years. The growing year strongly influenced nutritive characteristics of onion bulb. Higher average air temperature and lower amount of precipitation resulted in better nutritive quality. Among the measured nutritive constituents fibre and ash content was the least influenced by climatic factors.

\section{Aknowledgments}

This work was partly supported by Research Centre of Excellence 9878-3/2016/FEKUT Szent István University and TECH-09-A3-2009-0230 USOK2009 projects.

\section{References}

Abidin I, Maier HG (1980). Gleichzeitige Bestimmung von Fructose, Glucose und Saccharose mit der Anthron-Reaktion [Simultaneous determination of fructose, glucose and saccharose by Anthron assay]. Chemie, Mikrobiologie, Technologie der Lebensmittel 6:121-123.

Association of Official Analytical Chemists (AOAC) (1990). Official Methods of Analysis. Method 952.03/A-C. AOAC International (15th ed), Arlington, Virginia.

Brewster JL (2008). Onions and other vegetable Alliums. CABI (2nd ed), Wallingford, United Kingdom.

Caruso G, Conti S, Villari G, Borelli C, Melchionna G, Minutolo M, Russo G, Amalfitano C (2014). Effects of transplanting time and plant density on yield, quality and antioxidant content of onion (Allium cepa $\mathrm{L}$.) in southern Italy. Scientia Horticulturae 166(2):111-120.

Codex Alimentarius Hungaricus (2008). 3-2-2008/1 Élelmiszerek összes élelmi rosttartalmának a meghatározása enzimes-gravimetriás módszerrel [3-2-2008/1 Measurement of total dietary fibres in foodstuffs with enzymatic-gravimetric method].

Corzo-Martínez M, Corzo N, Villamiel M (2007). Biological properties of onions and garlic. Trendsin Food Science \& Technology 18(12):609-625.

Enciso J, Wiedenfeld B, Jifon J, Nelson S (2009). Onion yield and quality response to two irrigation scheduling strategies. Scientia Horticulturae 120(3):301-305.

European Standard (2003). BS EN 14130:2003 Foodstuffs. Determination of vitamin C by HPLC.

Franczuk J, Jablonska-Ceglarek R, Zaniewicz-Bajkowska A, Kosterna E, Rosa $R$ (2009). The effect of plant mulches on the nutritive value of red cabbage and onion. Vegetable Crops Research Bulletin 70(1):125134.

Kahlon MS, Singh CB, Sekhon NK (2011). Response of onion to irrigation and potassium application. Research on Crops 12(2):539544.

Khokar KM (2008). Effect of temperature and photoperiod on the incidence of bulbing and bolting in seedlings of onion cultivars of diverse origin. Journal of Horticultural Science \& Biotechnology $83(4): 488-496$.

Lee EJ, Suh JK (2009). Effect of temperature on the growth, pyruvic acid and sugar contents in onion bulbs. Korean Journal of Horticultural Science \& Technology 27(4):554559.
Lee SK, Kader AA (2000). Preharvest and postharvest factors influer vitamin $\mathrm{C}$ content of horticultural crops. Postharvest Biology and Technology 20(3):207-220.

Leskovar DI, Agehara S, Yoo K, Pascual-Seva N (2012). Crop coefficientbased deficit irrigation and planting density for onion: Growth, yield, and bulb quality. HortScience 47(1):31-37.

Mogren LM (2006). Quercetin content in yellow onion (Allium cepa L.): Effects of cultivation methods, curing and storage. $\mathrm{PhD}$ Thesis, Swedish University of Agricultural Sciences, Alnarp.

Mogren LM, Olsson ME, Gertsson UE (2006). Quercetin content in field cured onions (Allium cepa L.): Effects of cultivar, lifting time, and nitrogen fertilizer level. Journal of Agriculture and Food Chemistry 54(17):6185-6191.

Ombódi A, Koczka N, Lugasi A, Daood HG, Berki M, Helyes L (2013). Nutritive constituents of onion grown from sets as affected by water supply. HortScience 48(12):1543-1547.

Patil BS, Pike LM, Hamilton BK (1995). Changes in quercetin concentration in onion owing to location, growth stage, and soil type. New Phytologist 130(3):349-355.

Pejic B, Gvozdanovic-Varga J, Milic S, Ignjatovic-Cupina A, Krstic D, Cupina $B$ (2011). Effect of irrigation schedules on yield and water use of onion (Allium cepa L.). African Journal of Biotechnology 10(14): 26442652.

Pérez-Ortolá M, Knox JW (2015). Water relations and irrigation requirements of onion (Allium cepa $\mathrm{L}$.): A review of yield and quality impacts. Experimental Agriculture 51(2):210-231.

Rodrigues AS, Pérez-Gregorio MR, García-Falcón MS, Simal-Gándara J, Almeida DPF (2011). Effect of meteorological conditions on antioxidant flavonoids in Portuguese cultivars of white and red onions. Food Chemistry 124(1):303-308.

Rodríguez Galdón B, Tascón Rodríguez C, Rodríguez Rodríguez EM, Díaz Romero C (2009). Fructans and major compounds in onion cultivars (Allium cepa). Journal of Food Composition and Analysis 22(1):25-32.

Rubatzky VE, Yamaguchi M (1997). World vegetables: Principles, production and nutritive values. Chapman \& Hall (2nded),New York.

Slimestad R, Fossen T, Vagen IM (2007). Onions: A source of unique dietary flavonoids. Journal of Agricultural and Food Chemistry 55(25):10067-10080.

SmirnoffN (2011). Vitamin C: The metabolism and function of ascorbic acid in plants. Advances in Botanical Research 59:107-177.

Thompson L, Morris J, Peffley E, Green C, Paré P, Tissue D, Jasoni R, Hutson J, Wehner B, Kane C (2005). Flavonol content and composition of spring onions grown hydroponically or in potting soil. Journal of Food Composition and Analysis 18(7):635-645.

Tiwari U, Cummins E (2013). Fruit and vegetables. In: Tiwari BK, Brunton NG, Brennan CS (Eds). Handbook of plant food phytochemicals. Wiley-Blackwell, Chichester, United Kingdom pp 107-137.

Treutter D (2010). Managing phenol contents in crop plants by phytochemical farming and breeding - Visions and constraints. International Journal of Molecular Sciences 11(3):807-857.

Welbaum GE (2015). Vegetable production and practices. CABI, Wallingford, United Kingdom. 